Police, defense lawyer, representative of the staff of the probation authority. The state of administrative and legal regulation of providing the principle of juvenile specialization of participants of criminal proceedings in Ukraine is analyzed, as well as the prospects of its improvement are outlined.

It is stated that the mandatory legislation on specialization in criminal proceedings concerning minors contains the current legislation of Ukraine only with regard to judges and investigators. The specialization of other participants is partially traced only to the level of by-laws.

It is established that the so-called juvenile specialization in criminal proceedings should be achieved by combining the rules of criminal procedural law and the mechanism of administrative and legal regulation of providing such specialization. This will include the establishment in law of mandatory requirements for the specialization of the mentioned participants in criminal proceedings; selection of juvenile police as part of the National Police; defining the requirements for candidates and the conditions of their appointment, compulsory special education or advanced training determination of the basic body (institution) and approval of uniform standards of training of "juvenile" specialists, etc.

Key words: administrative and legal ensuring, child, criminal proceedings, minor, specialization, juvenile justice.

DOI: $10.33766 / 2524-0323.88 .92-101$

УДК 343.3/.7 (477)

М. В. Карчевський, доктор юридичних наук, професор, т. в. о. ректора Луганського державного університету внутрішніх справ імені Е. О. Дідоренка (м. Сєвєродонецьк, Україна) e-mail: comcriminal@gmail.com iDhttps://orcid.org/0000-0002-2693-3592 О. В. Одинцова, кандидат юридичних наук, старший викладач кафедри кримінально-правових дисциплін Луганського державного університету внутрішніх справ імені Е. О. Дідоренка

(м. Сєвєродонецьк, Україна)

e-mail: doslidnuk.lg.nik@gmail.com iD https:/ / orcid.org/0000-0003-3864-228X

\title{
АВТОМАТИЗОВАНА СИСТЕМА ДЛЯ ДОСЛІДЖЕННЯ ЗАКОНОДАВЧОЇ ОЦІНКИ СУСПІЛЬНОЇ НЕБЕЗПЕЧНОСТІ ДІЯННЯ «IN CONTЕХТ»
}

У статті окреслено основні завдання, які можуть ефективно вирішуватися за допомогою автоматизованої системи для дослідження законодавчої оцінки суспільної небезпечності діяння «In Context»; продемонстровано евристичні 
можливості системи для виявлення та візуалізації основних тенденцій розвитку кримінального законодавства, для аналізу співвідношення суворості санкцій за посягання на однорідні об'єкти; обгрунтовується перспективність ії використання для системного удосконалення кримінального законодавства.

Ключові слова: суспільна небезпека, законодавча оцінка суспільної небезпечності діяння, індекс контекстної законодавчої оцінки суспільної небезпечності, автоматизована система «In Context», інтенсивність санкцій кримінально-правових заборон, удосконалення законодавства про кримінальну відповідальність.

Постановка проблеми. Сучасне кримінально-правове законодавство характеризується тим, що не відповідає загальним вимогам щодо санкцій кримінально-правових заборон, які полягають у тому, що «..покарання, зазначене в санкції, має відбивати ступінь суспільної небезпечності названого в диспозиції діяння та бути узгодженим із санкціями статей, що передбачають відповідальність за вчинення інших, близьких за видом та характером злочинів» [1, с. 35]. Кримінальний кодекс України (далі - КК) набуває «рис розбалансованості» [2, с. 7-8]. Крім того, чинному КК властиві й такі недоліки, як: надмірна суворість або надмірна м'якість санкцій; невідповідність розмірів санкцій за злочини приблизно рівного ступеня суспільної небезпечності; невідповідність розмірів санкцій основного та кваліфікованого складів злочинів тощо [3; 4, с. 230]. Через недостатність методології досить часто законодавча оцінка суспільної небезпечності діяння не відповідає об'єктивним соціальним потребам у кримінально-правовому впливі, $\epsilon$ далекою від фактичної небезпечності посягання. Законодавчим оцінкам суспільної небезпечності властива суб' єктивність і відсутність єдиного виваженого підходу [5; 6].

Необхідність приведення законодавчих оцінок суспільної небезпечності кримінальних правопорушень у відповідність до їх фактичної небезпечності, а також відсутність універсальної та ефективної методології порівняння суворості санкцій зумовили розроблення методу контекстного дослідження законодавчої оцінки суспільної небезпечності [7; 8]. I хоча зазначений метод дозволяє ефективно вирішувати низку теоретичних та прикладних проблем кримінально-правового регулювання, проте, з урахуванням здобутків у галузі обробки великих масивів даних, існує нагальна потреба у візуалізації тенденцій розвитку кримінального законодавства, інтенсивності санкцій кримінальноправових заборон, побудові експериментальних моделей 3 приведення законодавчих оцінок суспільної небезпечності кримінальних правопорушень у відповідність до їх фактичної небезпечності. Через те логічним напрямом удосконалення методу стало посилення його евристичних можливостей за допомогою методів візуалізації та програмного засобу MS Excel: розроблено автоматизовану інформаційно-аналітичну систему для дослідження законодавчої оцінки суспільної небезпечності діяння «In Context».

Аналіз останніх досліджень і публікацій. У теорії кримінального права вже протягом тривалого часу звертають свою увагу на проблему розбалансованості санкцій кримінально-правових заборон Н. О. Гуторова, В. А. Мисливий, В. І. Осадчий, Ю. А. Пономаренко, Д. А. Плетньова, 
В. Д. Швець та інші дослідники. Доцільність саме системних змін у межах чинного КК обгрунтовують у своїх працях Ю. В. Баулін, В. І. Борисов, О.О.Дудоров, В. О. Навроцький, М. В. Карчевський, Ю. А. Пономаренко, В. Я. Тацій, М. І. Хавронюк та ін.

Проте методологічні основи порівняння кримінально-правових санкцій залишаються недостатньо розробленими. На сьогодні найбільш поширеним індикатором суворості санкцій є ї̈ медіана, яка дорівнює половині суми верхньої і нижньої межі санкції [9; 10]. Однак цей показник характеризується низкою недоліків, які значно обмежують можливості його використання. Поперше, він не враховує положення санкцій щодо додаткових покарань. Подруге, у разі порівняння покарань різних видів його використання пов' язане із застосуванням правил складання покарань (ст. $72 \mathrm{KK})$, серед яких відсутні положення щодо співвідношення таких покарань, як позбавлення волі на певний строк і штраф, а також позбавлення волі та позбавлення права обіймати декотрі посади або займатися певною діяльністю. Водночас, можливість представлення санкції, що передбачає таке покарання, як штраф у вигляді іншого покарання, існує. Для цього можна скористатися положеннями ч. 5 ст. 53 КК. Проте такий підхід себе не виправдовує, оскільки в разі дотримання правил, що містяться в згаданих нормах, не завжди одержуються результати, які можна використовувати для порівняння суворості санкції. Так, якщо спробувати представити мінімуми та максимуми санкцій у вигляді позбавлення волі та скористатися означеною формулою, медіана певних санкцій буде мати значення більше ніж верхня межа санкції (наприклад, ч. 1 ст. 197-1, ч. 1 ст. 362, ч. 3 ст. 176 КК та ін.). Нонсенс, до якого приходимо в цьому разі, свідчить, що метод не є універсальним.

Спроби обчисляти медіану в інший спосіб, наприклад як половину різниці максимальної та мінімальної меж санкції [6], призводять до аналогічних проблем і навіть створюють нові: у деяких випадках обчислені таким чином медіани для санкцій, які істотно відрізняються за ступенем тяжкості, є однаковими або медіана більш суворої санкції є меншою, ніж медіана менш суворої. Наприклад, санкція ч. 2 ст. 414 КК (від 2 до 10 років позбавлення волі) є менш суворою, ніж санкція ч. 3 ст. 399 КК (від 8 до 15 років позбавлення волі), однак медіана ч. 2 ст. 414 КК є більшою.

Іншим напрямом вирішення проблеми розбалансованості санкцій кримінально-правових заборон стало розроблення М. В. Карчевським методу контекстного дослідження законодавчої оцінки суспільної небезпечності та використання його при аналізі інтенсивності санкцій окремих груп злочинів.

Розроблення на його основі автоматизованої інформаційно-аналітичної системи для дослідження законодавчої оцінки суспільної небезпечності діяння «In Context» зумовлює необхідність осмислення іiі пізнавального потенціалу як у масштабі дослідження всієї Особливої частини КК, так й окремих груп кримінальних правопорушень, що мають спільні ознаки того чи іншого елементу складу кримінального правопорушення (потерпілий, предмет посягання, спосіб вчинення, суспільно небезпечні наслідки тощо). 
Формування цілей. Мета цієї роботи полягає в тому, щоб визначити основні завдання, які можуть ефективно вирішуватися за допомогою автоматизованої інформаційно-аналітичної системи для дослідження законодавчої оцінки суспільної небезпечності діяння «In Context», та на конкретних прикладах продемонструвати окремі ії евристичні можливості.

Виклад основного матеріалу. Уявімо, що певний кримінальний кодекс передбачає відповідальність всього за три кримінальні правопорушення: убивство, згвалтування та крадіжку. Нехай убивство карається найбільшим можливим для даного суспільства покаранням, згвалтування - у половину меншим покаранням, а за крадіжку передбачено покарання в розмірі до двох третин від максимально можливого за згвалтування. Таке законодавче визначення покарань є обгрунтованим та зрозумілим. Тоді як бути, коли заборон близько дев' яти сотень?

Сутність методу контекстного дослідження законодавчої оцінки суспільної небезпечності полягає в тому, що кожне кримінальне правопорушення розглядається $b$ контексті інших кримінальних правопорушень з позицій порівняння та зіставлення видів і розмірів покарань, які можуть бути за нього призначені. Вихідним положенням є аксіоматичне судження про те, що законодавча оцінка суспільної небезпечності певного посягання дається в санкції відповідної норми Особливої частини КК. Отже, для того щоб розглядати певну конкретну кримінально-правову заборону в контексті інших за ознакою законодавчої оцінки суспільної небезпечності, необхідно 3 урахуванням положень науки кримінального права порівняти суворість усіх санкцій, передбачених в Особливій частині КК, та систематизувати кримінально-правові заборони за цією ознакою. Місце, отримане певним посяганням у цій системі, і буде являти контекстну законодавчу оцінку суспільної небезпечності посягання.

Для інформативного представлення результатів пропонується використовувати числовий показник під назвою «індекс контекстної законодавчої оцінки суспільної небезпечності». Сутність цього показника полягає в тому, що він дозволяє представити місце, отримане конкретною кримінально-правовою забороною в результаті побудови описаного вище рейтингу, у вигляді числа зі значенням більше нуля, але не більше ста. Для найбільш небезпечного посягання він дорівнюватиме 100, для посягань, що знаходяться в середині побудованого рейтингу, - близько 50, індекс же посягань, що характеризуються найбільш м'якими санкціями, буде близьким до одиниці. ${ }^{\mathrm{I}}$

Розраховувати зазначений показник пропонується за формулою:

$$
I_{i}^{\mathrm{K} 30 с \mathrm{H}}=\frac{N \text { мax }-N_{\mathrm{i}}+1}{\text { ммах }} \times 100 \text {, де }
$$

- $I_{i}$ кзосн - індекс контекстної законодавчої оцінки суспільної небезпечності конкретного кримінально караного посягання; 


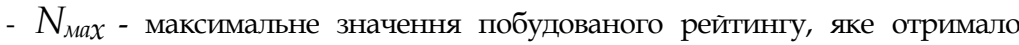
найменш небезпечне кримінально каране посягання;

- $N_{\text {i }}$ - числове вираження місця, яке отримало в побудованому рейтингу те посягання, для якого встановлюється індекс.

Метод реалізовано та здійснено його апробацію. Описаний алгоритм реалізовано в програмному засобі MS Excel. На основі методу розроблено інформаційно-аналітичну систему, яка дозволяе виконувати наступні завдання:

- порівнювати інтенсивність санкцій кримінально-правових заборон за допомогою методів візуалізації;

- здійснювати аналіз проектів законів щодо змін або доповнень до КК України з позицій обгрунтованості санкцій;

- отримувати науково обгрунтовану інформацію для розв'язання основного питання кримінально-правового регулювання - пошуку балансу між соціальною значимістю охоронюваних благ та інтенсивністю використовуваних кримінально-правових заходів;

- забезпечити базу для проведення компаративістських досліджень якісно нового рівня.

Використання запропонованого методу для дослідження кримінальноправового регулювання дозволить по-новому підійти до оцінки обгрунтованості суворості відповідних кримінально-правових санкцій. Контекстна законодавча оцінка суспільної небезпечності, на відміну від існуючих методів порівняння, забезпечує можливість аналізу кожної кримінально-правової санкції в порівнянні з генеральною сукупністю, що дозволяє з великою ймовірністю прогнозувати значну ефективність методу, наближення законодавчих оцінок суспільної небезпечності певних посягань до їх фактичної, об'єктивної небезпечності.

Достатньо перспективним видається використання розглянутого методу в законотворчій роботі. В. Я. Тацій указував на те, що «правотворчій діяльності останніх років багато в чому властивий безсистемний, а іноді навіть хаотичний характер, а законопроекти, що виносяться на розгляд парламенту, не завжди проходять належну наукову експертизу. Усе це, безумовно, знижує ефективність запобіжної функції закону про кримінальну відповідальність, негативно позначається на правозастосовній діяльності й призводить до нігілістичного ставлення громадян до вимог закону» [11, с. 17]. Аналізуючи можливі шляхи розвитку національного законодавства про кримінальну відповідальність, В.І. Борисов обгрунтовував доцільність саме системних змін у межах чинного КK $[12$, с. 283]. Установлення індексу контекстної законодавчої оцінки суспільної небезпечності в процесі роботи над проектами кримінально-правових норм дозволить чітко структурувати та скерувати дискурс щодо суворості санкції майбутньої норми, а отже, забезпечить системний підхід до вдосконалення КК, сприятиме попередженню законотворчих помилок.

Використання запропонованого методу може забезпечити певний розвиток i компаративістським кримінально-правовим дослідженням. 
Зрозуміло, що аналіз КК зарубіжної країни потребуватиме певного перегляду алгоритму порівняння та матриці даних залежно від передбаченої цим кодексом системи покарань.

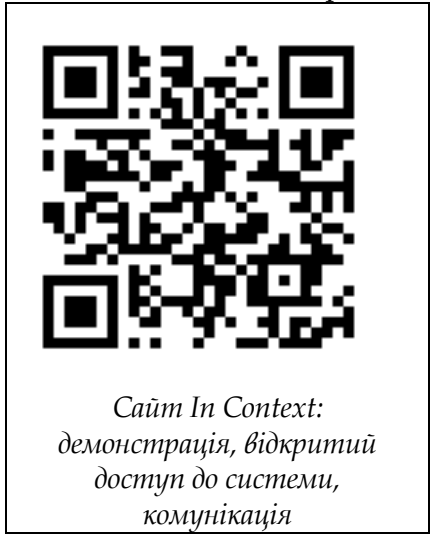

Приклади, що демонструються в наведеному на сайті відео, показують евристичні можливості системи, наочно представляють розбалансованість санкцій за необережне заподіяння смерті, а також спірний розподіл суворості санкцій за посягання, пов'язані 3 витоком інформації. Відтак, отримується інформація про те, як змінилася інтенсивність санкцій, що існували з 2001 року; пропонується інформативна візуалізація основного тренду розвитку кримінального законодавства, що полягає в розширенні предмету кримінально-правового регулювання; здійснюється системний прогноз зміни інтенсивності санкцій після набрання чинності Закону «Про внесення змін до деяких законодавчих актів України щодо спрощення досудового розслідування окремих категорій кримінальних правопорушення».

Висновки. Для продовження дискусії запропонуємо наступні висновки, що підтверджуються наведеними результатами роботи системи «In Context»:

- візуалізація змісту санкцій чинного кримінального законодавства підтверджує тезу про їх розбалансованість та необхідність системних змін;

- провідним трендом розвитку кримінального законодавства $е$ розширення предмету кримінально-правового регулювання та збільшення суворості санкцій;

- розгляд даного факту в площині раціональної парадигми кримінального права вимагає істотного перегляду підходів до законотворчої роботи, попередження кримінально-правового експансіонізму;

- перспективним видається використання представленої системи в процесі вдосконалення кримінального законодавства.

\section{Використані джерела:}

1. Дорош Л. В. Теоретико-прикладні проблеми якості кримінального законодавства України // Питання боротьби зі злочинністю : зб. наук. пр. / редкол.: В. І. Борисов та ін. Харків: Право, 2009. Вип. 18. С. 15-44.

2. Швець В. Д., Грицак В. М., Василькевич Я. І. та ін. Законодавча реалізація кримінально-правової політики: аналіз законопроектної діяльності Верховної Ради України V скликання з питань кримінального права; [вступне слово проф. Мельника М. І.]. Київ: Атіка, 2008. 244 с.

3. Пономаренко Ю. А. Щодо структури вчення про пеналізацію злочинів // Правові засади підвищення ефективності боротьби зі злочинністю $b$ Україні : матеріали наук. конф. (Харків, 15 травня 2008 р.) / редкол.: В. І. Борисов та ін. Харків: Право, 2008. C. $39-40$. 
4. Хавронюк М. І. Кримінальне покарання: що змінилося за останні п'ять тисяч років? // Кримінальний кодекс України 2001 р.: проблеми застосування $i$ перспективи удосконалення: тези доповідей та повідомлень учасників Міжнар. симпозіуму (Львів, 21 - 22 вересня 2012 р.). Львів: Львівський державний університет внутрішніх справ, 2012. С. 227-233.

5. Азаров Д. С., Калуп А. В. Кваліфікуючі ознаки складів злочинів: вибрані риторичні питання // Теоретичні та прикладні проблеми кримінального права України : матеріали міжнар. наук.-практ. конф. (м. Луганськ, 20 - 21 травня 2011 р.) / редкол.: Г. Є. Болдарь, А. О. Данілевський, О. О. Дудоров та ін.; МВС України, Луганський державний університет внутрішніх справ ім. Е. О. Дідоренка. Луганськ : РВВ ЛДУВС ім. Е. О. Дідоренка, 2011. С. 6-11.

6. Плетнева Д. А. О реализации принципа индивидуализации ответственности при построении санкций квалифицирующих составов // Держава i право: проблеми становлення $і$ стратегія розвитку : зб. матеріалів міжнар. наук.практ. конф. (Суми, 15 - 16 травня 2010 р.) / Сумська філія Харківського національного університету внутрішніх справ. Суми : ФОП Ляпощенко Л. Г., 2010. C. 241-244.

7. Карчевский Н. В. Метод контекстной законодательной оценки общественной опасности деяния и возможности его применения // Наука кримінального права в системі міждисииплінарних зb'язків : матеріали міжнар. наук.практ. конф. (Харків, 9-10 жовт. 2014 р.) / редкол.: В.Я . Тацій (голов. ред.), В. І. Борисов (заст. голов. ред.) та ін. Харків: Право, 2014. С. 115-121.

8. Карчевський М. В. Дослідження змін у законодавстві про кримінальну відповідальність за злочини у сфері господарської діяльності методом контекстної законодавчої оцінки суспільної небезпечності діяння. Вісник Луганського державного університету внутрішніх справ ім. Е. О. Дідоренка. 2013. № 2. С. 99-111.

9. Козлов А. П. Механизм построения уголовно-правовых санкций: автореф. дис. ... докт. юрид. наук. Москва, 1991. 38 с.

10. Філей Ю. В. Кримінально-правові санкції та їх застосування за злочини проти власності : автореф. дис. ... канд. юрид. наук. Львів, 2006. 18 с.

11. Тацій В. Я. Десять років Кримінальному кодексу України: здобутки і проблеми застосування. Право Украӥни. 2011. № 9. С. 5-19.

12. Борисов B. I. Основні напрямки розвитку Особливої частини законодавства України про кримінальну відповідальність // 10 років чинності Кримінального кодексу України: проблеми застосування, удосконалення та подальшої гармонізації із законодавством європейських країн : матеріали міжнар. наук.-практ. конф. (Харків, 13 - 14 жовтня 2011 р.) / редкол. : В. Я. Тацій (голов. ред.), В. І. Борисов (заст. голов. ред.) та ін. Харків : Право, 2011. С. 280-283.

\section{References:}

1. Dorosh, L. V. (2009). Teoretyko-prykladni problemy yakosti kryminalnoho zakonodavstva Ukrainy. Pytannia borotby zi zlochynnistiu - Issues of combating crime, issue 12, 15-44. [in Ukrainian].

2. Shvets, V. D., Hrytsak, V. M., Vasylkevych, Ya. I. et al. (2008). Zakonodavcha realizatsiia kryminalno-pravovoi polityky: analiz zakonoproektnoi diialnosti Verkhovnoi Rady Ukrainy V sklykannia z pytan kryminalnoho prava. Kyiv. [in Ukrainian]. 
3. Ponomarenko, Yu. A. (2008). Shchodo struktury vchennia pro penalizatsiiu zlochyniv. Pravovi zasady pidvyshchennia efektyvnosti borotby zi zlochynnistiu $v$ Ukraini: materialy nauk. konf. (Kharkiv, 15 travnia 2008 r.) - Legal basis for improving the effectiveness of crime fighting in Ukraine: Proceedings of the Scientific Conference. Kharkiv: Pravo, 39-40. [in Ukrainian].

4. Khavroniuk, M. I. (2012). Kryminalne pokarannia: shcho zminylosia za ostanni p'iat tysiach rokiv? Kryminalnyi kodeks Ukrainy 2001 r.: problemy zastosuvannia i perspektyvy udoskonalennia: tezy dopovidei ta povidomlen uchasnykiv Mizhnar. sympoziumu (Lviv, 21-22 veresnia 2012 r.) - Criminal Code of Ukraine 2001: Problems of Application and Prospects for Improvement: Abstracts and Reports of International Participants. the symposium. Kharkiv: Pravo, 227-233. [in Ukrainian].

5. Azarov, D. S., Kalup, A. V. (2011). Kvalifikuiuchi oznaky skladiv zlochyniv: vybrani rytorychni pytannia. Teoretychni ta prykladni problemy kryminalnoho prava Ukrainy : materialy mizhnar. nauk.-prakt. konf. ( Luhansk, 20 - 21 travnia 2011 r.) -Theoretical and applied problems of the criminal law of Ukraine: materials international. Research Practice Conf. Lugansk, 6-11. [in Ukrainian].

6. Pletneva, D. A. (2010). O realyzatsyy pryntsypa yndyvydualyzatsyy otvetstvennosty pry postroenyy sanktsyi kvalyfytsyruiushchykh sostavov. Derzhava $i$ pravo: problemy stanovlennia $i$ stratehiia rozvytku: $z b$. materialiv mizhnar. nauk.-prakt. konf. (Sumy, 15-16 travnia 2010 r.) - State and Law: Problems of Formation and Development Strategy: Coll. materials international. Research Practice Conf. Sumy: FOP Lyaposhchenko, 241-244. [in Ukrainian].

7. Karchevskyi, M. V. (2014). Metod kontekstnoj zakonodatel'noj ocenki obshhestvennoj opasnosti dejanija i vozmozhnosti ego primenenijaю. Nauka kryminalnoho prava $v$ systemi mizhdystsyplinarnykh zviazkiv: materialy mizhnar. nauk.-prakt. konf. (Kharkiv, 13 - 14 zhovtnia 2011 r.) - The science of criminal law in the system of interdisciplinary communication: materials inter. Research Practice Conf. (Kharkiv, October 9-10, 2014) V. Ya. Tatius,\& V. I. Borisov (Eds.) et al. Kharkiv: Pravo, 115-121. [in Ukrainian].

8. Karchevskyi, M. V. (2013). Doslidzhennia zmin u zakonodavstvi pro kryminalnu vidpovidalnist za zlochyny u sferi gospodarskoi diialnosti metodom konteksnoi zakonodavchoi otsinky suspilnoi nebezpechnosti diiannia. Visnyk Luhanskoho derzhavnoho universytetu vnutrishnikh sprav im. E. O. Didorenka - Bulletin of Lugansk State University of Internal Affairs named after E. O. Didorenka, 2, 99-111. [in Ukrainian].

9. Kozlov, A. P. (1991). Mekhanyzm postroenyia uholovno-pravovykh sanktsyi. Extended abstract of candidate's thesis. Moskva. [in Ukrainian].

10. Filei, Yu. V. (2006). Kryminalno-pravovi sanktsii ta yikh zastosuvannia za zlochyny proty vlasnosti. Extended abstract of candidate's thesis. Lviv. [in Ukrainian].

11. Tatsii, V. Ya. (2011). Desiat rokiv Kryminalnomu kodeksu Ukrainy: zdobutky i problemy zastosuvannia. Pravo Ukrainy - Law of Ukraine, 9, 5-19. [in Ukrainian].

12. Borysov, V. I. (2011). Osnovni napriamky rozvytku Osoblyvoi chastyny zakonodavstva Ukrainy pro kryminalnu vidpovidalnist. 10 rokiv chynnosti Kryminalnoho kodeksu Ukrainy: problemy zastosuvannia, udoskonalennia ta podalshoi harmonizatsii iz zakonodavstvom yevropeiskikh krain: materialy mizhnar. nauk.-prakt. konf. (Kharkiv, 13 - 14 zhovtnia 2011 r.) -10 Years of the Criminal Code of Ukraine: Problems of Application, Improvement and Further Harmonization with the Laws of European Countries: Materials International. Research Practice Conf. (Kharkiv, October 13 - 14, 2011). V. Ya. Tatsii, \& V. I. Borisov (Eds.) et al. Kharkiv: Pravo, 280-283. [in Ukrainian]. 
Карчевский Н. В.,

доктор юридических наук, профессор, вр. и. о. ректора Луганского государственного университета внутренних дел имени Э. А. Дидоренко

(г. Северодонецк, Украина)

Одинцова Е. В.

кандидат юридических наук, старший преподаватель кафедры уголовно-правовых дисциплин

Луганского государственного университета внутренних дел имени Э. А. Дидоренко (г. Северодонецк, Украина)

\section{АВТОМАТИЗИРОВАННАЯ СИСТЕМА ДЛЯ ИССЛЕДОВАНИЯ ЗАКОНОДАТЕЛЬНОЙ ОЦЕНКИ ОБЩЕСТВЕННОЙ ОПАСНОСТИ ДЕЯНИЯ «IN CONTEXT»}

В статье обозначены основные задачи, которые позволяет эффективно решать автоматизированная система для изучения законодательной оценки общественной опасности деяния «In Context», наглядно продемонстрированы ее эвристические возможности для выявления и визуализации основных тенденщий развития уголовного законодательства, для анализа соотношения суровости санкций за посягательства на однородные объекты. Обосновывается перспективность ее использования для системного усовершенствования уголовного законодательства.

Ключевые слова: общественная опасность, законодательная оценка общественной опасности деяния, индекс контекстной законодательной оценки общественной опасности, автоматизированная система «In Context», интенсивность санкций уголовно-правовых запретов, усовершенствование законодательства об уголовной ответственности.

Karchevskyi N., Doctor of Law, Professor, Acting Rector Luhansk State University of Internal Affairs named after E. O. Didorenko

(Sievierodonetsk, Ukraine)

Odintsova O.,

Candidate of Law,

Senior teacher of the Department of Criminal Law

disciplines Luhansk State University of Internal Affairs named after E. O. Didorenko

(Sievierodonetsk, Ukraine)

\section{THE AUTOMATED SYSTEM FOR RESEARCH LEGISLATIVE ESTIMATION OF PUBLIC DANGER OF ACT "IN CONTEXT"}

The article is devoted to the automated system for research legislative estimation of public danger of act "In Context". It was developed in MS Excel and based on the method of legislative assessment of the public danger of criminal offenses and methods of 
visualization. The essence of the method of legislative assessment of the public danger of criminal offenses is that each criminal sanction is analyzed in comparison with the general set of sanctions of the Special part of the Criminal code of Ukraine.

The article outlines the main tasks that can be efficiently accomplished through the automated system for research legislative estimation of public danger of act "In Context". The article describes and demonstrates the heuristic capabilities of the system for analysis the ratio of the severity of criminal penalties for offenses with homogeneous objects (for example, careless offenses on life and offenses related to information leakage), and to identify and visualize the main trends in the criminal law of Ukraine, for building a systematic forecast of changes in the intensity of criminal sanctions after the entry into force of the Law of Ukraine "On Amendments to Certain Legislative Acts of Ukraine on the Simplification of Pre-trial Investigation of Certain Categories of Criminal Offenses".

It is argued that an automated system for research legislative estimation of public danger of act "In Context" can become a promising tool for the systematic improvement of the legislation on criminal liability of Ukraine in the direction of reducing the imbalance of criminal sanctions, bringing legislative assessments of the public danger of criminal offenses in line with their actual danger and even preventing legal expansionism.

Key words: public danger, legislative estimation of public danger of act, the automated system "In Context", the intensity of criminal sanctions, index of contextual legislative estimation of public danger, the improvement of the legislation on criminal liability.

DOI: $10.33766 / 2524-0323.88 .101-112$

УДК 340.13:355-057.36

В. А. Мацько, науковий співробітник НДЛ

проблем правового та організаційного забезпечення діяльності Міністерства Державного науково-дослідного інституту МВС України (м. Київ, Україна) e-mail: mazko95@ukr.net iDhttps:// orcid.org/0000-0002-4149-8744

\section{ПОНЯТТЯ «УЧАСНИК ОПЕРАЦІІ ОБ'ЄДНАНИХ СИЛ (АНТИТЕРОРИСТИЧНОЇ ОПЕРАЦЇ̈) ЗА ЗАКОНОДАВСТВОМ УКРАЇНИ}

У статті досліджується поняття «учасник операції Об'єднаних сил (антитерористичної операції)» за законодавством України. За результатами проведеного аналізу чинного законодавства України та праць вітчизняних науковців за напрямом забезпечення прав учасників ООС/АТО, сформульовано авторське визначення поняття «учасник операції Об'єднаних сил (антитерористичної операції)». Наведено перелік документів, що підтверджують участь в ООС та АТО. Визначено існуючі прогалини в чинному законодавстві України, які регулюють питання надання статусу учасника бойових дій особам, які займаються волонтерською діяльністю.

Ключові слова: учасник операції Об'єднаних сил, учасник антитерористичної операції, ветеран війни, учасник бойових дій, доброволець, інвалід війни. 